\title{
Muslim Chaplain's Role as Perceived by Directors and Chaplains of New York City Hospitals and Health Care Settings
}

\author{
Wahiba Abu-Ras, Ph.D. \\ Adelphi University
}

\section{Abstract}

As more hospitals acknowledge the importance of spiritual care, there is an increasing demand for chaplains who can meet patients' spiritual needs. While most empirical studies thus far have focused on changes in chaplaincy services, and on the role of non-Muslim chaplains, very few have addressed the religious diversity among hospital chaplains and their roles in serving a diverse population. This study will be the first to examine the roles Muslim chaplains play in New York City hospitals and health care settings in general, and in serving Muslim patients in particular, as perceived by pastoral care directors and both Muslim and non-Muslim chaplains. This study used a mixed method of qualitative and quantitative, including a cross-sectional survey administered to 56 pastoral care directors and in-depth interviews with 33 Muslim and non-Muslim chaplains. Univariate and bivariate statistical analysis were used to analyze the quantitative data and a grounded thematic approach was employed to analyze the qualitative data. Results show that seven roles examined in this study were rated by most directors as being somewhat important to moderately important. The highest perceived importance mean given to Muslim chaplains' roles were handling directive education and organ donation (mean $=3.49$, SD 1.95), prayers (mean $=3.14$, $\mathrm{SD}=1.37$ ), and providing emotional support to patients and their families (mean $=3.13, \mathrm{SD}=1.35$ ). The perceived roles and activities are also different based on the location of the hospitals, the educational level of the directors, and faith affiliation of the directors and chaplains. The implication of this study is that addressing the cultural, racial, and ethnic disparities in health care settings, including chaplaincy services, is an important factor that could seriously impact health beliefs and behaviors. 


\section{Background and Significance}

Spirituality and religion are key strengths in personal well-being (Ellison \& Levin, 1998). Although distinct terms, they are overlapping and are often used interchangeably (Carroll, 1997), but delineation between chaplaincy and spiritual care services are drawn by perceived differences between religion and spirituality. According to Lee (2002), religion is referred to as "a social organization of belief and practice with a particular faith community" (p. 343; e.g., Roman Catholic, Methodist), and spirituality is understood as "the experiential integration of one's life in terms of one's ultimate values and meanings, without the institutional element connoted by religion" (p. 343). Spirituality has also been defined as a relationship with God, or some semblance of an ultimate power that fosters a sense of meaning, purpose, and mission in life (Carroll, 1997).

Pargament (1997) defines religious and/or spiritual coping as a "process that people engage in to attain significance in stressful circumstances" (p. 90). Based on this definition, one begins to wonder what role chaplains play and what services they are offering. Are they providing "pastoral care" (traditional ministry) or "spiritual care" (which carries a more generic connotation)?

Studies suggest that chaplaincy plays an important role in helping patients cope with physical illness (Emblen \& Pesut, 2001; Gatrad et al., 2004) and in supporting and strengthening patients' religious and spiritual beliefs and practices, particularly in the recovery process (Fogg, Weaver, Flannelly, \& Handzo, 2004; VandeCreek \& Lyon, 1997; VandeCreek, Siegel, \& Gorey, 2001). Many professionals and patients perceive the chaplain's role as dealing solely with end-of-life issues, where a clerical presence in a hospital ward may signify a patient's demise (Lee, 2002). Prayer, emotional support, and dealing with issues relating to grief and death were perceived to be very important elements of a chaplain's role, and conducting religious services, performing community outreach, consultation, and advocacy were viewed as moderately to very important (Flannelly et al., 2006). However, the degree of importance accorded to these roles varied considerably by discipline and hospital type (Flannelly et al., 2006), hospital size, location, and church affiliation (Cadge, Freese, \& Christakis, 2008). In psychiatric hospitals, for example, the chaplain's role was rated low in all categories except religious and ritual services (Flannelly et al., 2006), while in hospices, providing grief and bereavement support to patients' families and end-of-life services were among the most significant (Williams, 2004). In the United States, chaplains play a major role for the dying by providing spiritual support for patients and consoling their families (Hodgson, Segal, Weidinjjer, \& Linde, 2004; Flannelly et al., 2006). 
Lee (2002) argues the distinction between 'pastoral care' and 'spiritual care', which addresses the question of professional identity and determines how chaplains relate inter-professionally. Because chaplaincy services were a marginal part of the hospital organization, many administrators may readily admit that they do not understand the role and functions of chaplains, and therefore lead them to perceive these roles and functions to be limited (Lee, 2002). In one study, pastoral care directors rated the roles of chaplains highly across all areas and activities, physicians perceived the chaplain's role as important only in the area of religious service, and social workers did not rate the chaplain's role in providing end-of-life care to patients and emotional support to their families as equally important to religious serving (Flannelly et al., 2006).

Fogg, Weaver, Flannelly, and Handzo (2004) examined the reasons people were referred to chaplains in a hospital context and the types of issues patients wished to discuss. The study found that the most common reasons for a chaplain referral were simply to provide pastoral care and support and, more specifically, to help with depression, anxiety, and emotional distress. In addition, chaplains were sometimes asked to act as patient advocates, by contacting someone for crisis intervention or sharing good news and dealing with family issues (Fogg, Weaver, Flannelly, \& Handzo, 2004).

Another way of understanding chaplain roles and the activities they carry out in health care settings is by understanding who refers patients to chaplains. This is particularly important when many hospitals have a limit on spiritual assessment for patients and are more likely to rely on hospital staff. Galek and colleagues (2007) found that most referrals to chaplains were made by nurses with a high sense of spirituality and/or professionals outside of their discipline. These individuals were also reported to have high spiritual devotion which helped them identify the needs of the patients they served.

As more hospitals and other health-care institutions acknowledge the importance of spiritual care, there is an increasing demand for chaplains and clergy members who can meet patients' spiritual needs (McClung, Grossoehme, \& Jacobson, 2006). According to Amos (2007) "the word 'chaplain' has a Christian connotation. It means an authorized person who gives pastoral and spiritual care outside the main institutional structure of the Church" (p. 325). Recently, more efforts have been made to extend the traditional services of 'chaplaincy' to embrace the needs of multi-faith societies. In the United States since 1948, the Department of Health advised hospital authorities to provide spiritual care by appointing paid chaplains from different traditions and faith groups other than Christianity (Porter, 1999). In the United Kingdom, for example, chaplaincy context has moved from being applied in a Christian ecumenical fashion, to include other faith communities and provide more inclusive religious and 
spiritual services (Amos, 2007). Whereas the dominant Christian population in the United States still benefits the most from the clergy-turned-chaplains, little attention has been paid to the roles Muslim chaplains play in hospitals and health care settings and in addressing the needs of Muslim patients.

As of today, there are no accurate figures for the exact number of Muslims in the United States. However, some have estimated that Muslims are the second largest religious group in the world and one of the most rapidly growing religions in the United States (CAIR, 2005). Census estimates of Muslims in America range between 5.7 to 7 million (World Book). The annual growth rate of this population is $6 \%$, compared to the average national rate of .09\%, (Cornell University, 2002). Muslims also tend to be more concentrated in urban centers (Lubeck \& Britts, 2001). Many Muslim Americans have distinct spiritual and health care needs, especially as they relate to daily religious practices and worship, medical ethics, and end-of-life treatment choices; hence, the ability to clarify the specific values of Muslim patients with health care staff is critical (Hamza, 2007; Rassool, 2000). Ethical dilemmas arise regularly in today's highly technological health care systems, such as decisions to continue or withdraw aggressive treatment, and decisions regarding organ transplants and organ donations. Many Muslim patients draw from the Islamic legal tradition and engage religious scriptures to make health care decisions (Hamdy, 2008; Padela et al., 2008). Unavoidably, such personal dilemmas often intersect with the values and beliefs of secular staff members. Professional chaplains trained with cultural competence inclusive of Muslim traditions can serve as spiritual care liaisons between staff members and patients and their families.

Given the growing Muslim community in the United States, it is surprising that in New York City (NYC), where 600,000 Muslims reside (Abdelatif \& Minnite, 2002) and 70 hospitals operate, there are few Muslim chaplains. In 1992, the Association of Professional Chaplains awarded its first board certification to a Muslim hospital chaplain, Imam Yusuf Hassan (personal communication, 13 July 2009). Muslim chaplains are limited, however; there are only two boardcertified Muslim chaplains in over 70 hospitals operating in the five boroughs of New York City, and, according to D. Martino, Membership Coordinator of the Association of Professional Chaplains, eight board-certified Muslim chaplains in the entire United States (personal communication, 13 July 2009). Of all the chaplains currently serving NYC health care settings, there are very few trained Muslim chaplains, leaving the majority of the care to ecumenical chaplains who may not be able to adequately cater to the needs of Muslim patients.

VandeCreek and Lyon (1997) found that a patient's level of satisfaction increases when chaplains respond to diverse patient concerns in a sensitive manner. However, when a chaplain of a different religious denomination was asked to pray, the patient deemed the prayer to be inappropriate, even when 
the chaplaincy visit helped the patient address important medical, nursing, and administrative issues (VandeCreek \& Lyon, 1997). These findings were echoed by Hamza's (2007) argument on the lack of knowledge about minority patients' spiritual needs, and the existence of ethnic differences between the chaplain and patient which may negatively impact this relationship and its effectiveness. The ability to meet the needs of all patients is important, not only for the well-being of the patients themselves, but also for the entire hospital staff that seeks to maximize patient satisfaction and foster positive patient relations.

While most empirical studies thus far have focused on the changes in the chaplaincy services and hospital policies, and on the role of non-Muslim chaplains, very few have addressed the religious diversity among hospital chaplains and their roles in serving a diverse population. To the knowledge of the author, no study has been done to examine the roles Muslim chaplains play in hospitals and other health-care settings in general, and in serving Muslim patients in particular. This study will be the first to examine these roles as they are perceived by pastoral care directors as well as by Muslim and non-Muslim chaplains serving in NYC's hospitals.

\section{Methodology}

\section{Sample Selection and Recruitment Procedures}

This study utilized both quantitative and qualitative research methods. The quantitative part used a cross-sectional survey administered to 56 hospital pastoral care directors (from this point on referred to as directors) and the qualitative part used a series of in-depth, semi-structured interviews with 33 Muslim and non-Muslim hospital chaplains (from this point on referred to as chaplains) in hospitals and health care settings within the five boroughs of NYC (Manhattan, Brooklyn, Bronx, Queens, and Staten Island). A list of 45 directors at NYC hospitals was provided by the HealthCare Chaplaincy organization and another list of 40 directors was identified directly through hospital websites. A survey questionnaire and an invitation letter were mailed to all 85 potential directors inviting them to take part in the study. Six surveys were returned with incorrect addresses, and 56 surveys were completed and returned, for a response rate of $71 \%$.

For the face-to-face interviews, 40 hospitals were randomly selected from NYC's five boroughs. The investigator was granted 33 interviews in total. All interviews were conducted in English, in a hospital setting. All informed consent and study procedures were reviewed and approved by the Institutional Review Board of Adelphi University. 


\section{Measures}

The two separate study questionnaires were developed by the principal research investigator, and reviewed for construct validity by consensus by experts from Muslim Mental Health, Inc'.

The survey questionnaire consisted of two major sections. The first section was designed to obtain demographic information about general characteristics of the directors and the hospital/health care setting, including location, size, average number of patients in general and Muslim patients in particular. The second section used a 19-item scale, developed by Flannelly and colleagues (2006), on the importance of different chaplain roles and activities. The scale items were measured on a 6-point Likert-type scale $(0=$ not at all important to $5=$ extremely important). The scale items were divided into seven categories including: (a) grief and end-of-life care (items 1,2, \& 3); (b) emotional support to patients and their family members (items 16,17 , \& 18); (c) community liaison and outreach (items 7, 8, \& 9); (d) directives and organ donations (items 10 \& 11); (e) religious services and worship (items 4 \& 5); (f) consultation and advocacy (items 12, 13, 14, 15, \& 19); and (g) prayer (item 6). In this study the scale was slightly modified to reflect the perception of Muslim chaplains. For example, instead of asking the question in general terms ("In your opinion, how important is it to have chaplains be part of the palliative care team ..."), we added the word Muslim and the question reads "In your opinion, how important is it to have Muslim chaplains be part of the palliative care team?".

The semi-structured questionnaire used in the face-to-face interviews was developed by the investigator specifically for this study. Both measures aim to gather data on the: a) NYC hospitals and health care settings' sociodemographics; b) directors and chaplains' sociodemographics; c) Muslim chaplain's role as perceived by the directors and chaplains of NYC hospitals and health care settings.

\section{Statistical Analysis}

Univariate and bivariate statistical analysis were used to analyze the quantitative data and to determine the correlations among variables. Independent t-tests and analysis of variance methods were used to examine associations between perception of the Muslim chaplain's role and subjects' demographic data, education, gender, and the location of hospital. In order to further assess the important role of Muslim chaplains as perceived by the directors, several

1. Muslim Mental Health, Inc. is an organization committed to promoting research and educational activities, introducing Muslim mental health concepts and advancing culturally sensitive therapeutic approaches. For more information see their website at http://www.muslimmentalhealth.com/ 
statistical analyses were conducted. Pearson's correlation test was utilized to examine the relationship between seven categories of Muslim chaplains' roles and activities, as well as seven independent variables including (a) hospital size (number of licensed beds), (b) the average daily number of patients, (c) total number of chaplains by faith (Christian, Jewish, Muslim, and other) employed by hospitals, (e) gender, (f) directors' level of education (BA, MA, $\mathrm{PhD}$ ), and (g) location of hospitals (Manhattan, Brooklyn, the Bronx, Queens, and Staten Island). There were between one and three missing values for five cases; missing values were accounted for by replacement of means and median technique, for continuous and categorical values.

For the qualitative data, a grounded thematic approach was employed to analyze transcripts of all interviews using the computer-assisted qualitative data analysis software package, ATLAS.ti (2008). Each transcript was reviewed for emerging themes and processes for initial coding to develop a code book. Then a memo was written to generate theoretical codes and articulate a baseline understanding of the significant points. Based on the thematic findings of this question, all participants' responses were compared and contrasted.

\section{Findings}

\section{Sample Description}

Out of the 56 returned surveys, the majority of respondents ( $n=51,91.1 \%)$ reported having a pastoral care department. Of the total sample, three hospitals (5.4\%) handled pastoral care needs through the nursing department, and two hospitals (3.6\%) through the patient/social services department. Nearly half of the participants had the title "pastoral care director" and slightly more than half of the participants (56\%) were male. Most directors $(36 \%, n=20)$ and chaplains $(34 \%, n=11)$ in this study worked in Manhattan and Brooklyn hospitals $(27 \%, n=15 ; 21 \%, n=7$, respectively). The majority of the directors $(56 \%, n=28)$ and the chaplains $(70 \%, n=23)$ were male, and $66 \%$ of the participants held a master's degree or higher, sharing the same mean age of approximately 57 years. While none of the directors were Muslim, the chaplains represented a broader range of religious affiliation, including Christian (49\%, $n=16)$, Jewish $(21 \%, n=7)$, and Muslim chaplains $(30 \%, n=10)$. About twothirds of the directors $(66 \%, n=37)$ and the chaplains $(70 \%, n=23)$ served in general hospitals, most being non-profit institutions (see Table 1).

The vast majority $(91 \%, n=21)$ of the non-Muslim chaplains were employed full-time and paid directly by their hospitals, while two out of the 10 Muslim chaplains were employed full-time but paid directly by the state of New York. Half of the Muslim chaplains $(n=5)$ identified themselves as imams 
and worked as part-time chaplains. One imam worked as a volunteer, one was paid per-diem, and one was an intern in training. Of the 10 Muslim participants, one was a board-certified chaplain from the American Board of Certified Chaplains. About half $(48 \%, n=11)$ of the non-Muslim chaplains (four female and seven male) were board-certified.

The majority of hospitals ranged in size from medium to large (201 to $600+$ beds) facilities. The median number of licensed hospital beds reported by 52 directors was 382.5 (mean $=477, \mathrm{SD}=259.7$ ), while the median daily patient census for the 43 responding directors was 200 (mean $=241, \mathrm{SD}=$ 167.4). The median daily patient census by faith indicated that the majority were Jewish $($ median $=32.8$, mean $=61, \mathrm{SD}=78.8$ ), followed by Christian ( median $=20$, mean $=50, \mathrm{SD}=66.1)$, and then Muslim patients (median $=11.52$, mean $=17, \mathrm{SD}=19.7)$ and others $($ median $=12$, mean $=16, \mathrm{SD}$ $=19.3$ ) (see Table 2 ). Ninety-one percent $(n=54)$ of 54 responding directors employed paid chaplains; $75 \%(n=35)$ hired up to five chaplains-in-training

TABLE 1. Participants' characteristics and demographic background

\begin{tabular}{|c|c|c|c|c|}
\hline \multirow[b]{2}{*}{ Variable } & \multicolumn{2}{|c|}{ Directors } & \multicolumn{2}{|c|}{ Chaplains } \\
\hline & $N$ & (\%) & $N$ & (\%) \\
\hline Department & 56 & $(100.0 \%)$ & - & \\
\hline Nursing & 3 & (5.4\%) & - & \\
\hline Pastoral Care & 51 & (91.1\%) & 33 & $(100.0 \%)$ \\
\hline Patient/social Services & 2 & $(3.6 \%)$ & - & \\
\hline Gender: & 50 & $(100.0 \%)$ & 33 & $(100.0 \%)$ \\
\hline Male & 28 & $(56.0 \%)$ & 23 & (69.7\%) \\
\hline Female & 22 & $(44.0 \%)$ & 10 & $(30.3 \%)$ \\
\hline Education: & 56 & $(100.0 \%)$ & 33 & $(100.0 \%)$ \\
\hline $\mathrm{BA}$ & 6 & $(10.7 \%)$ & 5 & $(5.1 \%)$ \\
\hline MA & 39 & $(69.6 \%)$ & 20 & $(60.6 \%)$ \\
\hline Ph.D./Doctorate & 11 & (19.6\%) & 3 & $(9.2 \%)$ \\
\hline Average Age (in Years) & 56.5 & 56.7 & & \\
\hline Borough: & 56 & $(100.0 \%)$ & 33 & $(100.0 \%)$ \\
\hline Manhattan & 20 & $(35.7 \%)$ & 11 & (33.3\%) \\
\hline Brooklyn & 15 & $(26.8 \%)$ & 7 & (21.2\%) \\
\hline Bronx & 5 & $(8.9 \%)$ & 6 & (18.1\%) \\
\hline Queens & 12 & $(21.4 \%)$ & 5 & $(15.2 \%)$ \\
\hline Staten Island & 4 & (7.1\%) & 4 & (12.1\%) \\
\hline Type of Setting: & 56 & $(100.0 \%)$ & 33 & $(100.0 \%)$ \\
\hline General Hospital & 37 & (66.1\%) & 23 & $(69.7 \%)$ \\
\hline Long-Term care & 2 & (3.6\%) & 06 & $(18.2 \%)$ \\
\hline Psychiatric Hospital & 3 & (5.4\%) & 4 & $(2.1 \%)$ \\
\hline All the above/Hospice & 14 & $(24.9 \%)$ & - & - \\
\hline
\end{tabular}


TABLE 2. Hospital Size: Licensed Bed, and Average Daily Patients Census (AD $\mathrm{PC})$ in General and by Religion

\begin{tabular}{lcccc}
\hline $\begin{array}{l}\text { Average } \\
\begin{array}{l}\text { Patient Census } \\
\text { in general \& }\end{array} \\
\text { by faith }\end{array}$ & $N$ & Median & Mean (SD) & Range \\
\hline Overall Licensed bed & 52 & 382.5 & $447(259.7)$ & $100-1200$ \\
General ADPC & 43 & 200.0 & $241(167.4)$ & $30-693$ \\
Christian ADPC & 43 & 50.0 & $50(66.1)$ & $0-285$ \\
Jewish ADPC & 42 & 32.8 & $61(78.8)$ & $0-403$ \\
Muslim ADPC & 43 & 11.5 & $17(19.7)$ & $0-0$ \\
Other ADPC & 42 & 12.0 & $16(14.3)$ & $0-60$ \\
Total Muslim patients & 34 & 27.0 & $130(338.2)$ & $0-1800$ \\
$\quad$ served per year** & & & & \\
\hline
\end{tabular}

$\star \star 39 \%(n=22)$ participants did not have statistics about Muslim patients or they are unaware/ unsure

(chaplains who already obtained some training in chaplaincy services but were not board-certified); $62 \%(n=26)$ of 42 responding directors hired up to five board-certified chaplains; $89 \%(n=46)$ of 53 responding directors contacted local clergy (including priests, rabbis, and imams); and 61\% ( $n=34)$ of 56 responding directors used staff members (physicians and nurses) for chaplaincy services. The majority of 47 responding directors $(70 \%, n=33)$ reported that they hired up to five full-time paid chaplains, and $47 \%(n=22)$ recruited up to 10 unpaid volunteer chaplains (Table 3).

Overall, the majority of the participants tend to perceive the Muslim chaplain's role as moderately to definitely important. As Table 4 shows, the highest perceived importance given to Muslim chaplains' roles were handling directive education and organ donation (mean $=3.49, \mathrm{SD} 1.95)$, prayers $($ mean $=3.14$, $\mathrm{SD}=1.37$ ), and providing emotional support to patients and their families (mean $=3.13, \mathrm{SD}=1.35)$. The least perceived important activities and roles of

TABLE 3. Mean and Median Number of Employed Professional Chaplains (EPC) and Volunteer Chaplains (VC) By Faith

\begin{tabular}{lcccl}
\hline Number of EPC by faith & $N$ & Median & Mean (SD) & Range \\
& 52 & 2 & $3.0(4.0)$ & $0-21$ \\
Christians & 51 & 1 & $1.0(0.8)$ & $0-4$ \\
Jews & 49 & 0 & $0.3(0.8)$ & $0-1.5$ \\
$\quad$ Muslims & 49 & 0 & $0.2(0.5)$ & $0-2$ \\
$\quad$ Other & & & & \\
Number of unpaid VC by faith & 44 & 4 & $9.0(14)$ & $0-66$ \\
$\quad$ Christians & 43 & 1 & $3.0(6)$ & $0-30$ \\
Jews & 43 & 0 & $0.7(1)$ & $0-4$ \\
$\quad$ Muslims & 44 & 0 & $1.3(2)$ & $0-9$ \\
$\quad$ Other & & & & \\
\hline
\end{tabular}


TABLE 4. Comparative Results between Perceived Muslim Chaplains Roles and the National Study of Flannelly et al. (2006)

\begin{tabular}{lcc}
\hline & $\begin{array}{c}\text { Muslim Chaplains Role } \\
\text { Study (2006) } \\
\text { Mean (SD) }\end{array}$ & National Flannelly et al. \\
\hline end-of-life support & $2.75(1.32)$ & $4.46(0.71)$ \\
conduct religious services & $2.81(1.42)$ & $3.65(1.16)$ \\
prayers & $3.14(1.37)$ & $4.51(0.76)$ \\
community liaison and outreach & $2.62(1.35)$ & $3.63(0.97)$ \\
directive education & $3.49(1.95)$ & $2.58(1.31)$ \\
consultation & $2.80(1.25)$ & $3.93(0.80)$ \\
emotional support & $3.13(1.35)$ & $4.53(0.67)$ \\
\hline
\end{tabular}

the Muslim chaplains were acting as community liaisons and doing outreach (mean $=2.62, \mathrm{SD}=1.35)$, providing end-of-life support (mean $=2.75, \mathrm{SD}=$ 1.32 ), providing consultation (mean $=2.80, \mathrm{SD}=1.25$ ), and conducting religious services $($ mean $=2.81, \mathrm{SD}=1.42)$, range $=0-15)$.

The relationship between the perceived importance role of Muslim chaplains and other independent variables

The Pearson correlation show only a significant correlation between participants from hospitals that employed Jewish professional chaplains (EJPC) and the roles of end-of-life support $(\mathrm{r}=.28, \mathrm{p}<.05)$, religious services $(\mathrm{r}=.42, \mathrm{p}<$ $.01)$, consultation $(\mathrm{r}=.35, \mathrm{p}<.01)$, and emotional support $(\mathrm{r}=.32, \mathrm{p}<.05)$. EJPC accounted for $7.8 \%, 17.6 \%, 12.25 \%$, and $10.24 \%$ of the variance on these roles, respectively (Table 5). Directors who worked in hospitals that employed Jewish professional chaplains are more likely than their counterparts to perceive Muslim chaplains' roles as significantly important in providing end-oflife support, religious services, consultation, and emotional support.

Muslim chaplain roles and the effect of gender and education

The results of the independent t-test show no significant differences between the two genders on any of their roles. However, the one-way ANOVA shows a significant difference $(\mathrm{F}=2.87, \mathrm{p}<.05)$ between the three education levels on the importance of the role of Muslim chaplains in providing services related to end-of-life support. The results of the post-hoc Bonferroni correction show that directors with doctorate degrees $($ mean $=10.27)$ placed greater importance on Muslim chaplains' roles as related to "end-of-life support" (mean = 7.49), and in "praying" with Muslim patients and their families $(\mathrm{F}=2.43, \mathrm{p}<.05)$ than those with other degrees; the Fisher's least significant difference post-hoc 
TABLE 5. Correlation Between perceived role of Muslim Chaplains and other Independent Variables

\begin{tabular}{lccccccc}
\hline & $\begin{array}{c}\text { No. of } \\
\text { Licensed } \\
\text { bed }\end{array}$ & $\begin{array}{c}\text { Everage } \\
\text { pategories of the } \\
\text { role of chaplains }\end{array}$ & $\begin{array}{c}\text { Professional } \\
\text { Chaplains } \\
\text { (EPC) }\end{array}$ & $\begin{array}{c}\text { No. of } \\
\text { Certified } \\
\text { Chaplains }\end{array}$ & $\begin{array}{c}\text { EPC by } \\
\text { Christians } \\
\text { faith }\end{array}$ & $\begin{array}{c}\text { EPC by } \\
\text { Muslim } \\
\text { faith }\end{array}$ & $\begin{array}{c}\text { EPC by } \\
\text { Jewish } \\
\text { faith }\end{array}$ \\
\hline end-of-life support & .03 & -.01 & -.13 & -.08 & -.05 & -.026 & $.28^{\star}$ \\
religious services & -.01 & .01 & -.08 & -.11 & -.01 & .040 & $.42^{\star *}$ \\
prayers & .04 & -.04 & -.21 & -.15 & -.15 & -.095 & .18 \\
community liaison & .01 & .03 & -.10 & -.07 & -.07 & .070 & .22 \\
directive education & .01 & .05 & -.10 & -.02 & -.06 & .038 & .15 \\
consultation & .08 & .05 & -.11 & -.09 & -.08 & -.023 & $.35^{\star *}$ \\
emotional & .04 & -.00 & -.16 & -.12 & -.09 & -.050 & $.32^{\star *}$ \\
\hline${ }^{*} p<0.05$ level (1-tailed & & & & & &
\end{tabular}

test shows that directors with doctorate degrees place greater importance on Muslim roles in providing prayer services (mean $=3.73$ ) than participants with masters' degrees (mean=2.89).

Perception of Muslim chaplain's role based on location

The independent $\mathrm{t}$-test results show that there were significant differences $(\mathrm{t}$ $(d f=54)=-2.09, \mathrm{p}<.05)$ between Manhattan $($ mean $=5.68)$ and other areas $($ mean $=4.32)$ in one role: Directors who work in Manhattan hospitals are more likely to put a greater importance on the role of Muslim chaplains in the area of directive education on organ donations. No other significant differences were found with the other six role categories based on location.

\section{Results of the face-to-face interviews}

Overall, Muslim and non-Muslim chaplains agree that having Muslim chaplains on the hospital team is very important. As a non-Muslim chaplain stated "I would love to have an imam who could come, but nobody wants to volunteer their services". Another chaplain perceived the importance of Muslim chaplains as providing a more culturally sensitive role: "For example, halal meat, services during holidays, sensitivity for Muslim issues, and fasting during Ramadan. It has to come from outside, not inside." One Muslim chaplain suggests that Muslim chaplains need to take responsibility for increasing the number of supplies such as Qur'ans, prayer beads, and halal foods.

A non-Muslim chaplain assigned what would seem like an unusual role for Muslim chaplains to take on themselves, which was overcoming negative stereotypes about Muslims among staff: 
TABLE 6. Perceived Muslim Chaplains' Role by Participants Educational Level

\begin{tabular}{|c|c|c|c|c|c|c|}
\hline \multicolumn{2}{|c|}{$\begin{array}{l}\text { Role/activities category by } \\
\text { education }\end{array}$} & \multirow{2}{*}{$\frac{N}{6}$} & \multirow{2}{*}{$\begin{array}{r}\text { Mean } \\
9.50\end{array}$} & \multirow{2}{*}{$\frac{S D}{3.51}$} & \multirow{2}{*}{$\frac{F}{2.865}$} & \multirow{2}{*}{$\frac{p^{*}}{.033}$} \\
\hline end-of-life support & $\mathrm{BA}$ & & & & & \\
\hline & MA & 39 & 7.49 & 3.75 & & \\
\hline & $\mathrm{PhD}$ & 11 & 10.27 & 3.35 & & \\
\hline & Total & 56 & 8.25 & 3.78 & & \\
\hline \multirow[t]{4}{*}{ religious services } & BA & 6 & 7.00 & 3.03 & 1.853 & .084 \\
\hline & MA & 39 & 5.18 & 2.73 & & \\
\hline & $\mathrm{PhD}$ & 11 & 6.45 & 2.25 & & \\
\hline & Total & 56 & 5.63 & 2.72 & & \\
\hline \multirow[t]{4}{*}{ prayers } & BA & 6 & 3.67 & 1.63 & 2.433 & .049 \\
\hline & MA & 39 & 2.89 & 1.28 & & \\
\hline & $\mathrm{PhD}$ & 11 & 3.73 & 1.01 & & \\
\hline & Total & 56 & 3.14 & 1.31 & & \\
\hline \multirow[t]{4}{*}{ community liaison } & $\mathrm{BA}$ & 6 & 9.00 & 4.34 & 1.577 & .108 \\
\hline & MA & 39 & 7.26 & 3.79 & & \\
\hline & $\mathrm{PhD}$ & 11 & 9.36 & 3.75 & & \\
\hline & Total & 56 & 7.86 & 3.88 & & \\
\hline \multicolumn{7}{|c|}{ directive education on } \\
\hline \multirow[t]{4}{*}{ organ donation } & BA & 6 & 4.67 & 2.16 & 1.755 & .091 \\
\hline & MA & 39 & 4.49 & 2.33 & & \\
\hline & Ph.D. & 11 & 6.00 & 2.61 & & \\
\hline & Total & 56 & 4.80 & 2.41 & & \\
\hline \multirow[t]{4}{*}{ consultation } & $\mathrm{BA}$ & 6 & 14.33 & 6.25 & 1.444 & .123 \\
\hline & MA & 39 & 13.55 & 6.22 & & \\
\hline & $\mathrm{PhD}$ & 11 & 17.00 & 4.56 & & \\
\hline & Total & 56 & 14.31 & 5.99 & & \\
\hline \multirow[t]{4}{*}{ emotional support } & BA & 6 & 11.00 & 4.43 & 1.851 & .083 \\
\hline & MA & 39 & 8.74 & 4.02 & & \\
\hline & PhD & 11 & 10.82 & 2.56 & & \\
\hline & Total & 56 & 9.39 & 3.89 & & \\
\hline
\end{tabular}

*One-Tailed Hypothesis

It would be so great to have more Muslim chaplains to counteract how people feel about Muslims post-9/11. There's fear out there about Muslims. Chaplaincy can change this and serve to counterbalance this perception. If you had an imam/Muslim chaplain sitting in the CPE [Clinical Pastoral Education] group, people would get to know him. If he made rounds, people would see that Muslims are not so bad.

One Muslim chaplain perceived the role of a Muslim chaplain as an educator, and reported being asked to explain to hospital staff about fasting and taking medications, and about head coverings and beards. While a Muslim chaplain perceived the role of a Muslim chaplain as counselor in "talking with patients about the meaning of their illness," a non-Muslim chaplain perceived the role of a Muslim chaplain as an educator on "organ donation." Another suggests the 
role of Muslim chaplains as cultural brokers to overcome some interaction barriers with Muslim patients. Although some board-certified Muslim and nonMuslim chaplains report that they are trained to overcome interaction barriers between Muslim patients and non-Muslim chaplains, a Muslim chaplain said that these barriers are easier to overcome for imams/Muslim chaplain than for non-Muslim chaplains: "Once a chaplain was making the rounds and visited a female Muslim patient. He felt that she was not being receptive to him. He informed her that there was an imam here, and she wanted to see him."

At least three non-Muslim chaplains perceived the Muslim role as helpful in providing prayer services, especially in dealing with Muslim patients and because of their [non-Muslim chaplains] "being Catholic" and "lack of knowledge, lack of specific training in Muslim culture and prayer, no comfort level with prayers," or due to "certain restrictions" in Islam.

A group of six chaplains, diverse by religious affiliation and certification, suggested that a Muslim chaplain or imam would be able to diagnose their [Muslim patients] needs better, especially relating to special Muslim prayers for the sick. Another group of six non-Muslim chaplains suggested that Muslim patients should be treated as individuals with specific needs, and recommend having an imam or Muslim chaplain assess Muslim patients' needs for prayer, support, a pastoral visit, or a consultation on medical decisions, and making any reasonable accommodations for them. Another chaplain described the role of the chaplain as a counselor in "helping people make connections to traverse the crisis they're in". She also explains the chaplain's role as advocate: "A chaplain sitting on interdisciplinary rounds will be told that a patient feels disconnected, displaced...this advocacy role is an important aspect of providing Muslim patients with a safe, respectful environment in which to heal". In other words, Muslim chaplains seem to resolve Muslim patient needs that are often unaddressed in hospitals. Two Muslim chaplains perceived the Muslim chaplains role as someone who provide Muslim patients with a theological perspective on illness, framing the experience in terms of a personal jihad: "A personal jihad is to persevere, to struggle, to push on through crises. It's a struggle with the soul to push through something. Illness is a part of personal jihad - to push through."

Muslim and non-Muslim chaplains agreed that one of the most important role and activity of Muslim chaplains is providing prayer services. All ten Muslim chaplains report that having very distinguished roles in praying and reciting the Qur'an with patients, and two say they offer whatever literature they can find in a patient's language. One Muslim chaplain said: "If [the patient] needs any reading materials, whatever resources I have, I will supply. I prepared some verses from the Qur'an." Another Muslim chaplain sees the role of Muslim chaplains as an advisor. For example, he advises Muslim patients on 
alternative forms of performing ritual physical worship when disabled by illness or constrained by medical devices.

Other frequently mentioned roles of Muslim chaplains in relation to Muslim patients are only mentioned by Muslim chaplains. Muslim chaplains also articulate their role as providing both spiritual guidance and education about faith and practice to Muslim patients, and some include their role as Friday prayer preachers (Muslim staff and patients' families are the primary beneficiaries of this service). They also mentioned other rituals of reciting specific prayers at birth, participating in male circumcisions, and reciting verses of the Qur'an while someone is dying. End-of life services seem to be of special importance.

\section{Discussion}

The study results show that the vast majority of the directors and chaplains serve in Manhattan and Brooklyn and mainly in general hospitals and nonprofit health care settings. Consistent with the range of ideas about what chaplains do and how their roles are perceived, this study highlights the range of perceived roles that directors and chaplains participants have assigned to Muslim chaplains. These perceived roles and activities are different based on the location of the hospitals, the education level of the directors, and faith affiliation of employed chaplains.

All seven roles examined in this study were rated by most directors as being somewhat important to moderately important; the roles of chaplains used in the national study conducted by Flannelly and colleagues (2006) were mostly rated as definitely to very important (see Table 4). The most commonly, but moderately rated, perceived roles Muslim chaplains have were in providing directive education, providing emotional support, and providing prayers, respectively, while the least important perceived roles were serving as a community liaison and doing outreach, providing end-of-life support, consultation services, and conducting religious services, respectively. Prayer services were supported by Handzo and colleagues' (2008) study of the type of religious and spiritual intervention among Catholic, Muslim, Jewish, and Protestant chaplains. He found that Muslims were among the highest (76\%) to report prayers as the most frequent use of intervention by Muslim chaplains. Surprisingly, discussing organ donation and following directives received the highest rate across all other categories and was rated as definitely important; this is in contrast with Flannelly and colleagues' (2006) study which rated this as significantly less important than the other six categories across all disciplines and hospital types.

Muslim and non-Muslim chaplains assigned a high rate of importance to various roles Muslim chaplains play, starting with providing prayers and 
religious services, educating staff and patients on ethical and ritual concerns regarding the meaning of illness, providing emotional support to patients and their family members, advising, and conducting special rituals prayers and ceremonies ("end-of-life prayer", "sick prayers", and "newborn prayers"), consulting on organ donations, and celebrating holidays and the fasting month of Ramadan. Other important roles participants assigned to Muslim chaplains were acting as "cultural brokers," as "client advocates" in addressing the lack of services available to Muslim patients, and in promoting Muslims' positive image by removing stereotypes.

Generally, most chaplains have traditionally fulfilled a central role both in the delivery of spiritual care and in providing end-of-life support. It is important to note that the major focus given by directors and Muslim and non-Muslim chaplains to the Muslim chaplain's role within the hospitals was no longer perceived as a spiritual or religious provider only, but this role was extended to include non-traditional roles such as providing directives and consultations to patients and their family members, and to other chaplains, physicians, and hospital staff members, depending on the patient's needs and concerns. These non-traditional roles are specifically important when many patients are coming from other faith and ethnic groups who may encounter ethical issues and dilemmas that often intersect with the values and beliefs of the western-trained staff members. Other dilemmas arise regularly in today's highly technological health care systems, such as decisions to continue or withdraw aggressive treatment, and decisions regarding organ transplants and organ donations (Hamdy, 2008; Padela et al., 2008).

The perceived role of the Muslim chaplains also varied based on hospital location by borough, and the level of the directors' level of education. For example, directors working in Manhattan had an increased emphasis on Muslim chaplains in reference to organ donations in comparison to the other hospital locations. In addition, directors with higher educational background valued more Muslim chaplain's role in providing assistance with prayers, end-of- life support, and praying with the patients and their families than their counterparts. More importance was given by directors on the Muslim chaplain's role on rituals of prayers, such as at birth, and reciting the Qur'an at times of death or newborn baby.

Directors and chaplains were asked about the special spiritual services Muslim chaplains provide. Although, non-Muslim chaplains perceived themselves to be knowledgeable and professional enough to serve all patients, and able to address all patients' spiritual needs, they also reported support from Muslim chaplains or local imams if needed. To most non-Muslim chaplains, all chaplaincy training combines religious education and training in pastoral counseling with vital knowledge of all faiths. These results are supported by previous studies (Abu-Ras, in press; Abu-Ras \& Laird, 2011) indicating that 
most non-Muslim chaplains and directors of NYC hospitals "do alright on their own" serving Muslim patients, suggesting that Muslim chaplains are not necessary because Muslims' needs are being met. On the other hand, only Muslim chaplains reported to be familiar enough with all issues concerning Muslim patients. They believed that they can produce viable and culturally sensitive services to Muslim patients, including reciting verses from the Qur'an, praying together, providing spiritual literature, having knowledge of Islamic codes of ethics and belief systems, and being able to provide a higher level of comfort and more meaningful support.

Although some directors and most non-Muslim chaplains believe they know how to address Muslim patients' needs, they perceive the role of Muslim chaplains as important, especially among directors and chaplains who serve in Manhattan hospitals and in hospitals where more Jewish chaplains are employed. This indicates that hospitals located in urban areas are more likely to have a more culturally savvy approach to patients in addressing their specific and distinct needs. They also seem to be more appreciative of cultural differences and keener to meet the distinct needs of diverse patient populations by either reaching out to the Muslim community, local imams, or to hospitals' Muslim staff members. In other words, hospitals that employ chaplains from other faith than Christians are more likely to assign a greater importance to Muslim chaplains' roles and activities than hospitals that only offer chaplaincy accommodation to patients from a dominant faith. This is not to suggest that Christian chaplains do not show appreciation to other faith, but that their perceptions may reflect on the hospital policies and their spiritual approaches and services offered or available to the use of other ethnic, religious, and minority groups.

Prayers and religious rituals were also acknowledged as a central role of Muslim chaplains. Most non-Muslim chaplains expressed some challenges in addressing these roles and activities with Muslim patients, but they tend to value the role of Muslim chaplains most when it comes to special prayers and reciting from the Qur'an. Chaplains not only provides prayers and religious services, but are a comforting representative of the faith community where the patient came from. Amos (2007) describes the role of the chaplain as a key link between the patient and the community from which the patient might otherwise feel separated at this critical juncture (p. 329). To Amos, this link does not apply in the same way if the chaplain is a from a faith community that is different from the patient's.

On the other hand, smaller hospitals and those located in rural areas were less likely to have Muslim chaplains on their staff than larger hospitals. Smaller and/or rural hospitals might not have resources available to hire chaplains and/ 
or there may be less need because local religious leaders are more readily available (Cadge, Freese, \& Christakis, 2008).

Practice and policy implications

As the United States becomes a more racially and ethnically diverse nation, health care systems and providers need to respond to patients' varied perspectives, values, and behaviors about health and well-being. Failure to understand and manage social and cultural differences may have significant health consequences for minority groups in particular. Health care experts in government, managed care, academia, and community health care make a clear connection between cultural competence, quality improvement, and the elimination of racial/ethnic disparities. Although, cross-cultural training has been recommended, and required in some health care settings, more cultural components need to be integrated in the training and professional development of health care providers at all levels.

The literature shows that religious and spiritual beliefs support positive mental health (Koenig et al., 1992, 1999; Pargament, 1997), physical health (Koenig et al., 1988, 1991, 1998, 2001; Luskin, 2000; Powell et al., 2003), and the prevention of illness, while providing psychological benefits and social resources across divergent religious communities (Koenig et al., 1991; Koenig, 2008, 2009; McNichol, 1996). Mental health research also has demonstrated that American Muslims are more likely to report emotional or psychosocial problems to spiritual leaders, imams (Muslim leaders), and chaplains than to mental health professionals (Abu-Ras et al., 2008; Ali et al., 2005). Hence, it is important for mental and physical health providers to recognize the varying perceptions of chaplains' roles, specifically in the area of emotional support to patients and to family members.

In addition, regarding the provision of chaplaincy services for Muslim patients, some have argued that non-Muslim-trained chaplains must be educated in the practice of Islam as it specifically relates to illness and death (Rassool, 2000). Others have argued that chaplains who share a similar ethnic or cultural background with their patients are more likely to reach their patients (Hamza, 2007). Despite this, Muslim chaplains are limited; there are only two boardcertified Muslim chaplains in over 70 hospitals operating in the five boroughs of New York City, and, according to D. Martino, Membership Coordinator of the Association of Professional Chaplains, only eight board-certified Muslim chaplains in the entire United States (personal communication, 13 July 2009).

At the policy level, special consideration must be given to the differences between Muslim and non-Muslim patients' needs. To increase the use of spiritual care services among Muslim patients, chaplains and hospitals must 
identify the important roles Muslim chaplains can offer and the special approaches they take in addressing Muslim patient needs. Such policies may include board-certified chaplaincy training for Muslim chaplains, the utilization of community-based imams, and interfaith Clinical Pastoral Education residents-in-training. While suggesting that the professional training and certification of Muslim chaplains is one component of improving patient care, it is also recognized that the very structure of Muslim religious leadership in the United States is often de-differentiated. In addition, all health professionals need to recognize varying perceptions of health shared by people from different religious, sociocultural, and ethnic backgrounds in order to deliver culturally sensitive healthcare.

In the United States, historically chaplains have been predominantly Christian, which has primarily benefited the dominant Christian populations. However, during the twentieth century, a new wave of religious leaders began advocating for an interfaith approach to multiethnic chaplaincy care. Scholars wished to develop a more pragmatic model to address and support the spiritual and religious needs of people from diverse religious and cultural backgrounds (Gatrad et al., 2003). In a recent study, Abu-Ras and Laird (2011) found that non-Muslim chaplains use a "one size fits all" approach to chaplaincy that suggests that non-Muslim chaplains approach Muslim patients in much the same way they approach other patients, and that the resulting strategies used to satisfy Muslim patients' needs are deemed sufficient. Despite the evolution of pastoral care from a religious-based service to one of universal appeal, it has clear limitations when used with Muslim patients. In Abu-Ras and Laird's study, non-Muslim chaplains recognized the need for an imam when Muslim patients needed a specific ritual, or in "life and death" situations. Investigating how Muslims currently in chaplaincy training programs negotiate the integration of the interfaith CPE model with religious traditions may provide greater insight into the barriers and challenges of increasing the availability of professional Muslim hospital chaplains.

The success of meeting the needs of Muslim patients and all patients has strong public health policy implications. At the service and patient level, the findings could help inform chaplaincy providers and health service planners as to improving the appropriateness, relevancy, and effectiveness of services for Muslim patients. At the local level, reaching out to Muslim patients may help narrow the gap between hospital health care providers and community-based Muslim spiritual care providers. On a broader level, by providing appropriate services to patients, patients are more likely to experience positive change, and more likely to overcome physical and emotional challenges. The positive outcome will likely decrease the number of days of hospitalization and minimize the economic burden that chaplaincy services place on hospitals and health care settings. 
In the United States, chaplaincy services are typically designed and practiced according to a paradigm of pastoral care or "spiritual care" for all, regardless of religious affiliation. Chaplains, though most often trained, paid, and credentialed by specific denominational institutions, nevertheless frequently serve outside those particular boundaries of religious affiliation. Accordingly, many of the non-Muslim chaplains and directors in our study argued that they are knowledgeable enough to care for all patients regardless of their faiths. While several chaplains acknowledge their own ignorance of Islam and doubts about their ability to discern Muslim needs, they still argue that Muslim chaplains are not necessary because Muslims have the same needs as everyone else. Even when these attitudes are acknowledged, healthcare providers (including chaplains) may provide unequal care to minorities.

Despite the evolution of pastoral care from a religious-based service to one of universal appeal, many chaplain-researchers argue that there are limits to this model which, in effect, seems to be a Protestant-based chaplaincy model camouflaged as an interfaith model of CPE/chaplaincy (Schmidt \& Egler, 1998; Mohrmann, 2008; DeVries, Berlinger, \& Cadge, 2008; Lee, 2002). Schmidt \& Egler (1998) delineate some of the limitations in caring for Muslim patients by citing several spiritual activities such as end-of-life discussions, rituals and prayer which require specific knowledge, at least according to Islam. They suggest that chaplains must go beyond generic services that are based on "formal" common ground, and often lack the ability to provide the "content" required or requested by Muslim patients (Schmidt \& Egler, 1998). Other scholars argue that the separation of individual "spirituality" from the religious community and religious practices is not possible within an Islamic framework (Stoll et al., 1989; Rassool, 2000). Furthermore, when it comes to the patients' perceptions of illness and death, a prominent Islamic response is acceptance and understanding of God's will. Athar $(1993,1998)$ points to the Islamic belief that illness atones for sins (although Muslims are expected to seek appropriate care and treatment for their illnesses), and death is part of the journey of life.

\section{Limitations}

The findings of this study should be interpreted in light of the following limitations. This study cannot be generalized based on the limitations of the sample size as well as the method of recruitment. The study relied on a small, nonrandom sample of participants from only the five boroughs of NYC. In addition, the study was conducted only in English and thus excludes non-Englishspeaking chaplains. The participants were recruited from hospitals and health care settings, which excludes other potential community organizations such as 
mosques. Future studies on the role of Muslim chaplains should also include the perspective of Muslim patients. The qualitative interviews were conducted with a small, non-random sample of chaplains. Our sample included a diverse range of settings and training backgrounds, and oversampled for Muslim chaplains. The transcripts were analyzed by only one coder, introducing the possibility of subjective bias in interpreting the data. We were able to identify, through constant comparison between transcripts and grounded thematic analysis, significant repeating themes that portray attitudes toward, experiences with, and approaches to Muslim patients. With greater accuracy in recording (the use of digital recorders), a finer analysis of chaplains' discourse about Muslim patients would be possible. We also recognize that attitudes, opinions, and experiences may be shaped by degrees of experience with Muslim patients; we did not attempt to analyze the organization and triaging practices of chaplaincy services in our sample. Since the Muslim community is culturally and religiously diverse, future studies should better control for ethnicity and other individual backgrounds. These limitations potentially constrained the author from making generalizations based on the findings because the data may not be representative of other subject populations. There may be factors, in terms of size and composition of the healthcare system, chaplaincy staffing, and Muslim patient population that are unique to New York City. A more comprehensive national study could illuminate these factors more clearly.

\section{Conclusion}

Muslims are an increasingly visible presence in US hospitals, as both providers and patients. Healthcare professionals need to better understand how chaplaincy care services are delivered to Muslim patients. Both the demand for and supply of spiritual care providers must be addressed. Special consideration must be given to the differences between Muslim and non-Muslim patients' needs. To increase the use of spiritual care services among Muslim patients, chaplains and hospitals must identify barriers and develop approaches to remove them. One means is through coherent and comprehensive chaplaincy training for Muslim chaplains, community-based imams, and interfaith CPE residents-in-training.

This study has identified several major roles Muslim chaplains may have and some concerns in addressing Muslim patient's needs from the perspective of the pastoral care directors and the Muslim and non-Muslim chaplains. From the directors' and non-Muslim chaplains' perspective, there is a lack of knowledge regarding Islam and a lack of specific cultural competency. The Muslim chaplain's perspective addresses several concerns, such as not being 
a full-time, not being fully paid by the hospitals, not being certified, or welltrained in chaplaincy services.

All health professionals need to recognize varying perceptions of chaplains' roles serving a diverse population and health shared by people from different religious and ethnic backgrounds in order to deliver culturally sensitive healthcare services. The results of this study could help inform chaplaincy providers and health care policymakers and planners to improve the appropriateness, relevancy, and effectiveness of services for Muslim patients.

\section{References}

Abu-Ras, W. (in press). Assessment of the existing chaplaincy and spiritual care services for minority groups as perceived by chaplains and directors of New York City hospitals: The case of Muslim patients. Topics in Integrative Health Care: An International Journal.

Abu-Ras, W., Gheith, A. \& Cournos, F. (2008). Imams' role in mental health promotion: A study at 22 mosques in New York Muslim community. Journal of Muslim Mental Health, 3157-178.

Abu-Ras, W., \& Laird, L. (2011). How Muslim and non-Muslim chaplains serve Muslim patients: Does the interfaith chaplaincy model have room for Muslims' experiences? Journal of Religion and Health, 50, 46-61.

Ali, O., Milstein, G., \& Marzuk, P. (2005). The imam's role in meeting the counseling needs of Muslim communities in the United States. Psychiatric Services, 56, 202205.

Amos, A. (2007). Death in hospital: The place of religion in the care of the patient. Islam and Christian-Muslim Relations, 18, 325-331.

Athar, S. (1993). Islamic perspectives in medicine. A survey of Islamic medicine: Achievements and contemporary issues. Indianapolis: American Trust Publications.

Athar, S. (1998). Information for health care providers when dealing with a Muslim patient. Islamic Medical Association of North America, Illinois, 1-3.

ATLAS.ti. (2008). Version 5.5.9. Berlin, Germany: ATLAS.ti GmbH.

Bagby, I. Perl, P. M., and Froehle, B. T. (2005). Council on American-Islamic Relations (CAIR). American Muslim: Population statistics. Retrieved on 03-31. from[http:// care-net.org.asp/populationstats.asp]

Cadge, W., Freese, J., \& Christakis, N.A. (2008). The provision of hospital chaplaincy in the United States: a national overview. Southern Medical Journal, 101(6), 626-630.

Carroll, M. M. (1997). Spirituality and clinical social work: Implications of past and current perspectives, Arete, 22(1), 25-34.

Cornell University, 2002. In: Dey, F., and Mistler, B., (nd). Identity and career development issues and interventions with Muslim clients in the US. Retrieved June 10, 2010 from[http://www.crc.ufl.edu/uploadedFiles/About_Us/Conference_Paper/ Praying.pdf]

De Vries R, Berlinger N, Cadge W. (2008). Lost in Translation: The Chaplain's Role in Health Care. In: Hastings Center Report: Hastings Center, p. 23-27. 
Ellison, C. G., \& Levin, J. S. (1998). The religion-health connection: Evidence, theory, and future directions. Health Education and Behavior, 24, 700-720.

Flannelly, K. J., Galek, K., Bucchino, J., Handzo, G. \& Tannenbaum, H. P.(2005).Department Directors' Perceptions of the Roles and Functions of Hospital Chaplains: A National Survey. Hospital Topics, 83(4), 19-27

Flannelly, K. J., Handzo, G. F., Weaver, A. J. and Smith W. J (2006). A national survey of health care administrators' views on the importance of various chaplain roles. Journal of Pastoral Care \& Counseling, 59 (1/2), 87-96.

Flannelly, K. J., Handzo, G. F., Weaver, A. J. and Smith W. J. (2004). Factors affecting health care chaplaincy and the provision of pastoral care in the U.S. Journal of Pastoral Care and Counseling, 58(1-2), 127-130.

Fogg, S. L., Weaver, A. J., Flannelly, K. J. and Handzo, G. F. (2004). An analysis of referrals to chaplains in a community hospital. Journal of Pastoral Care \& Counseling, 58 ( 3), 225-235.

Galek, K., Flannelly, K. J., Koeing, H. G., \& Fogg, S.L. (2007). Referrals to chaplains: The role of religion and spirituality in health care sittings. Mental Health, Religion, and Culture, 10 (4), 363-377.

Gatrad, A.R., Brown, E. and Sheikh, A., (2004). Developing multi-faith chaplaincy. Archives of Disease in Childhood, 89 (6), 504-505.

Gatrad, A. R., Sadiq, R., \& Sheikh, A. (2003). Multifaith chaplaincy. The Lancet, 362, 748. (August 30). Retrieved on March 31, 2011, from www.thelancet.com.

Hamdy, S. (2008).Rethinking Islamic legal ethics in Egypt's organ transplant debate. In EJ Brockopp \& T Eich (Eds) Muslim Medical Ethics: From Theory to Practice. Columbia: University of South Carolina Press, 78-96.

Hamza, Doha Raik (2007). 'On models of hospital chaplaincies: Which one works best for the Muslim Community? Journal of Muslim Mental Health, 2(1), 65 - 79.

Handzo, G.f., Flannelly, K.J. Kudler, T., Fogg, S.T., Harding S.R., et al, (2008. What do chaplains really do? II. Intervention in the New York chaplaincy study. Journal of Health Care Chaplaincy, 14(1), 39-56

Hodgson, N.A., Segal, S., Weidinjjer, M., and Linde, M.B. (2004). Being there: contributions of the nurse, social worker, and chaplain during and after a death. Generations, 28(2), 47-52

Jacobs MR. What Are We Doing Here? (2008). Chaplains in Contemporary Health Care. In: Hastings Center Report: Hastings Center, 15-18.

Lee, S. J. C. (2002). In a secular spirit: strategies of clinical pastoral education. Health Care Analysis 10(4), 339-356.

Levin, J. S. \& Taylor, R. J. (1997). Age differences in patterns and correlates of the frequency of prayer. Gerontologist, 37, 75-88.

Lubeck, P. and Britts, B., 2001. Muslim civil society in urban public spaces: globalization, discursive shifts, and social movements. In: J. Eade and C. Mele, eds. Understanding the City: Contemporary and Future Perspectives. Blackwell: Oxford, 305306.

McClung, E., Grossoehme, D. H., \& Jacobson, A.F. (2006). Collaborating with chaplains to meet spiritual needs. Nursing, Vol. 15(3), 147-156.

Mohrmann, M.E., (2008). Ethical Grounding for a Profession of Hospital Chaplaincy. In: Hastings Center Report: Hastings Center, p. 18-23. 
Padela, A.I., Shanawani, H., Greenlaw, J., Hamid, H., Aktas, M., \& Chin, N. (2008). The perceived role of Islam in immigrant Muslim medical practice within the USA: an exploratory qualitative study. Journal of Medical Ethics, 34, 365-369.

Pargament, K. (1997). The Psychology of religion and coping: Theory, research, practice. New York: Guilford Publications.

Porter R. (1999).The greatest benefit to mankind: a medical history of humanity from antiquity to the present. London: Fontana.

Princeton Religion Research Center. (1994). Religion in America (1994 supplement). Princeton, NJ: Gallup Poll.

Rassool, H. (2000). The crescent and Islam: healing, nursing and the spiritual dimension. Some considerations towards an understanding of the Islamic perspectives on caring. Journal of Advanced Nursing, 32(6), 1476-1484.

Schmidt, K.W. and G. Egler, A (1998). Christian for the Christians, a Muslim for Muslims? Reflections on a Protestant View of Pastoral Care for all Religions. Christian Bioethics, 4(3): 239-256.

Stoll, U. R. \& Stoll, U. I. (1989). The Essence of Spirituality in Spiritual Dimensions of Nursing Practice (Garson V.B., ed), W.B. Saunders, Philadelphia

VandeCreek, Larry, L. \& Lyon, M. (1997). Ministry of hospital chaplains: Patient satisfaction. The Journal of Health Care Chaplaincy, 6(2), 1-61.

VandeCreek, L. (2001). A White Paper. Professional chaplaincy: its role and importance in healthcare. Journal of Pastoral Care, 55(1), 81-97.

VandeCreek, L., Siegel, E., \& Gorey, J. (2001). How many Chaplains per 100 inpatients? Benchmarks of Health Care Chaplaincy Departments

The World Almanac, World Almanac Books, NY, 2011

\section{Acknowledgement}

The author would like to thank her Research Assistant, Ms. Tricia Moscato, for all her help and support. 